\title{
Prediksi Peningkatan Debit Puncak Sungai Serayu Berdasarkan Perubahan Penggunaan Lahan
}

\author{
Prediction of Increase in Serayu River Peak Discharge Based on Land Use \\ Change
}

\author{
Teguh Marhendi ${ }^{*}$, Anggit Aji Pramono \\ 1,2)Program Studi Teknik Sipil, Fakultas Teknik dan Sains \\ Universitas Muhammadiyah Purwokerto \\ *email: tmarhendi@gmail.com,teguhmarhendi@ump.ac.id
}

\author{
DOI; \\ 10.30595/jrst.v3i1.3048
}

Histori Artikel:

Diajukan:

$01 / 08 / 2018$

Direvisi:

$14 / 01 / 2019$

Diterima: $25 / 01 / 2019$

\begin{abstract}
ABSTRAK
Perubahan penggunaan lahan yang tidak sesuai kaidah konservasi dapat mengurangi tingkat resapan air tanah dan dapat meningkatkan puncak banjir. Daerah Aliran Sungai Serayu Hulu, sejak tahun 2011-2016 terus mengalami perubahan penggunaan lahan. Penelitian ini bertujuan untuk menganalisis perubahan penggunaan lahan menggunakan ArcGIS.10.3. Perubahan penggunaan lahan yang digunakan antara tahun 2011-2016 dengan prediksi perubahan antara 2017 - 2026. Analisis prediksi dilakukan menggunakan model persamaan statistika. Prediksi debit puncak di dianalisis pada titik kontrol Bendung Gerak Serayu untuk mengetahui perubahan debit puncak antara tahun 2017 - 2026. Hasil analisis menunjukan perubahan penggunaan lahan untuk kawasan vegetasi tahun 2011 - 2016 mengalami penurunan sebesar 9,46\%, sedangkan bukan vegetasi mengalami kenaikan sebesar 44,46\%.. Hasil prediksi debit puncak di titik kontrol Bendung Gerak Serayu pada tahun 2017 - 2026 relatif mengalami kenaikan, yaitu: $\mathrm{Q}_{2017}=655,55 \mathrm{~m}^{3} / \mathrm{s}, \mathrm{Q}_{2018}=675,90 \mathrm{~m}^{3} / \mathrm{s}, \mathrm{Q}_{2019}=693,85 \mathrm{~m}^{3} / \mathrm{s}, \mathrm{Q}_{2020}=$ $709,91 \mathrm{~m}^{3} / \mathrm{s}, \mathrm{Q}_{2021}=724,43 \mathrm{~m}^{3} / \mathrm{s}, \mathrm{Q}_{2022}=737,69 \mathrm{~m}^{3} / \mathrm{s}, \mathrm{Q}_{2023}=749,89$ $\mathrm{m}^{3} / \mathrm{s}, \mathrm{Q}_{2024}=761,18 \mathrm{~m}^{3} / \mathrm{s}, \mathrm{Q}_{2025}=771,70 \mathrm{~m}^{3} / \mathrm{s}, \mathrm{Q}_{2026}=781,53 \mathrm{~m}^{3} / \mathrm{s}$.
\end{abstract}

Kata kunci: Penggunaan Lahan, Prediksi Peningkatan Debit, Regresi Linear, Bendung Gerak Serayu

\begin{abstract}
Unsuitable land use change can reduce groundwater catchment and increase peak flood. The Upper Serayu River Basin, from 2011-2016 continues to experience changes in land use. This Research aims to analyze land use changes using ArcGIS.10.3. Land use change used in this study between 2011-2016 with predicted changes between 2017 - 2026. Prediction analysis is done using statistical equation model. The prediction of peak discharge is analyzed at the control point of Bendung Serak to determine the peak discharge change between 2017 - 2026. The analysis shows that land use change for vegetation from 2011 to 2016 decreased by $9.46 \%$, while non-vegetation area increased by $44.46 \%$. The result of prediction of peak discharge at Motegi Serayu Control point in 2017 - 2026 is relatively increasing, that is: Q2017 = 655,55 m3 / s, Q2018 = 675,90 m3 / s, Q2019 $=693,85 \mathrm{~m} 3 / \mathrm{s}, \mathrm{Q} 2020=709,91 \mathrm{~m} 3 / \mathrm{s}, \mathrm{Q} 2021=724,43 \mathrm{~m} 3 / \mathrm{s}, \mathrm{Q} 2022=737,69 \mathrm{~m} 3 / \mathrm{s}, \mathrm{Q} 2023=$ 749,89 m3 / s, Q2024 = 761,18 m3 / s, Q2025 = 771,70 m3 / s, Q2026 = 781,53 m3 / s.
\end{abstract}

Keywords: Land Use, Inflow Increase Prediction, Linear Regression, Serayu Barrage 


\section{PENDAHULUAN}

Seiring dengan peningkatan jumlah penduduk di Indonesia, permasalahan lingkungan hidup dari tahun ke tahun menjadi semakin komplek. Pertambahan jumlah penduduk akan selalu menuntut kebutuhan lahan, sehingga berimplikasi terhadap perubahan penggunaan lahan. Untuk memenuhi kebutuhan tersebut, manusia cenderung memanfaatkan lahan kearah penggunaan yang lebih tinggi daya gunanya maupun meningkatkan potensi lahannya. Pratama W. (2016), menyatakan bahwa setiap perlakuan yang diberikan pada sebidang tanah dapat mempengaruhi tata air di tempat tersebut dan tempat - tempat di hilirnya.

Perubahan tata guna lahan adalah berubahnya penggunaan lahan dari satu sisi penggunaan ke penggunaan yang lain diikuti dengan berkurangnya tipe penggunaan lahan yang lain dari suatu waktu ke waktu berikutnya atau berubahnya fungsi lahan suatu daerah pada kurun waktu yang berbeda (Wahyunto dkk., 2001). Perubahan penggunaan lahan dapat mengakibatkan terjadinya perubahan tutupan lahan. Perubahan fungsi tutupan lahan dari kawasan konservasi (lahan hijau) menjadi kawasan terbangun (permukiman) akan memperberat tekanan terhadap kondisi lingkungan antara lain pengaruhi besarnya laju erosi dan sedimentasi di wilayah hulu, menimbulkan banjir dan genangan diwilayah hilir, serta tanah longsor dan kekeringan (Sudarto, 2009). Penggunaan lahan (land use) juga diartikan sebagai setiap bentuk intervensi (campur tangan) manusia terhadap lahan dalam rangka memenuhi kebutuhan hidupnya baik materil maupun spiritual, sedangkan perubahan tutupan lahan lebih kepada adanya perubahan vegetasi (Nilda, 2014, Wijaya, K. 2011)..

Kabupaten Banyumas memiliki luas lahan $1.327,59 \mathrm{~km}^{2}$ atau setara dengan $132.759,56$ ha dan dengan jumlah penduduk sebanyak 1.650.625 jiwa. Sepanjang tahun 2011-2016, telah terjadi perubahan penggunaan lahan di wilayah Kabupaten Banyumas atau di Daerah Aliran Sungai Serayu di atas Bendung Gerak Serayu (Badan Pusat Statistik Kabupaten Banyumas, 2017). Perubahan penggunaan lahan tersebut memberikan pengaruh terhadap perubahan puncak banjir yang terjadi di titik kontrol Bendung Gerak Serayu.

\section{METODE PENELITIAN}

\subsection{Lokasi Penelitian}

Lokasi penelitian ini dilakukan di Kabupaten Banyumas atau di Daerah Aliran Sungai Serayu hulu dengan titik kontrol di hulu Bendung Gerak Serayu yang terletak di Desa Kebasen Kecamatan Patikraja Kabupaten Banyumas Jawa Tengah.

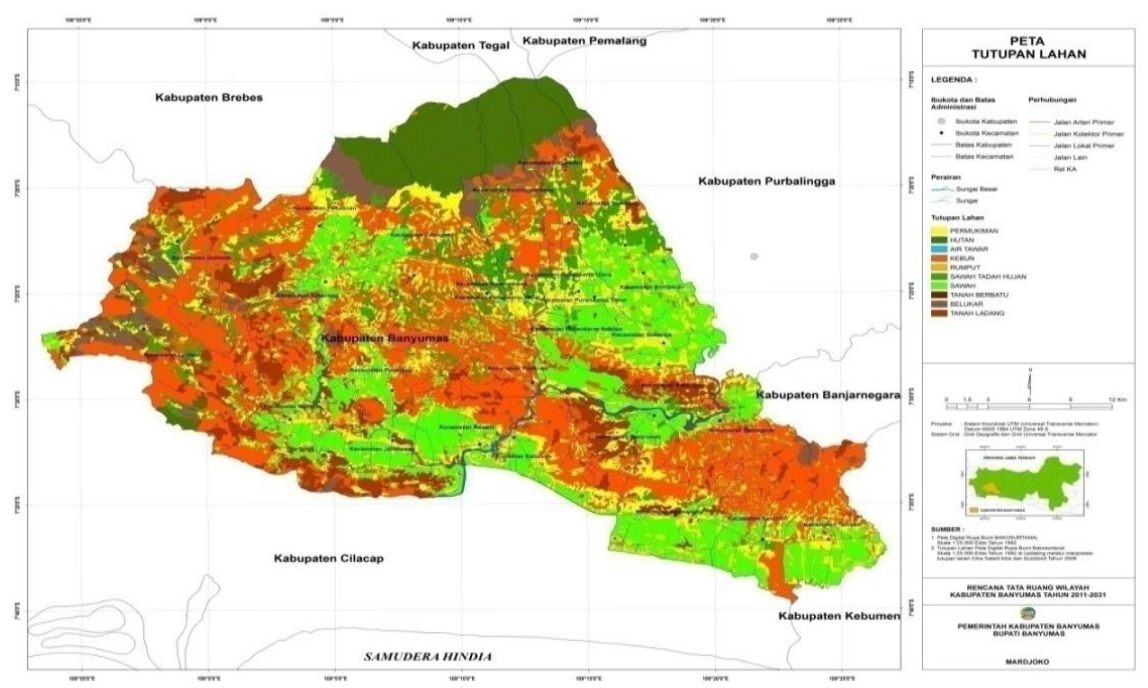

Gambar 1. Peta Tutupan Lahan Kabupaten Banyumas

(Sumber : Badan Perencanaan Pembangunan dan Litbang Daerah Kabupaten Banyumas, 2012) 


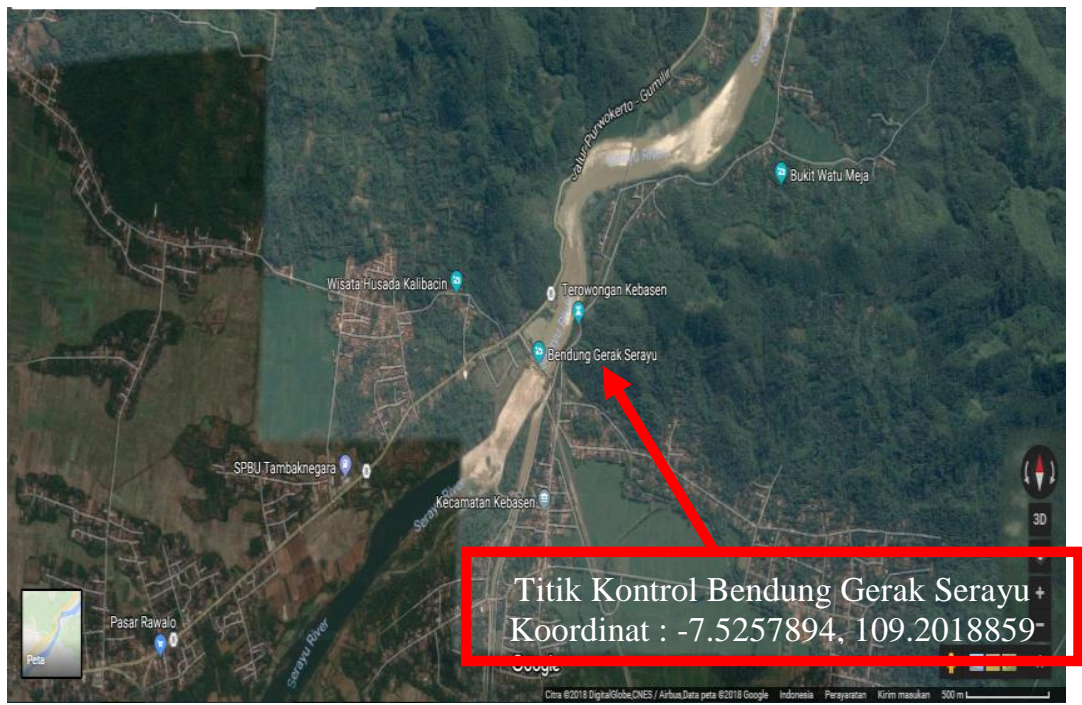

Gambar 2. Lokasi Penelitian di Titik Kontrol Bendung Gerak Serayu

(Sumber : Google Maps, 2018)

\subsection{Pengumpulan Data}

Data sekunder yang digunakan dalam penelitian ini meliputi data hidrologi berupa debit aliran Sungai Serayu di titik kontrol Bendung Gerak Serayu tahun 2011 - 2016. Data ini diperoleh dari Balai Pengelolaan Sumber Daya Air Serayu Citanduy. Data lain yang digunakan berupa data penggunaan lahan Kabupaten Banyumas tahun 2011 - 2016 dari Badan Pusat Statistik Daerah Kabupaten Banyumas dan Badan Perencanaan Pembangunan dan Litbang Daerah Kabupaten Banyumas.

\subsection{Analisis Penggunaan lahan}

Analisis penggunaan lahan diperlukan untuk mengetahui perubahan penggunaan lahan sepanjang tahun data yang digunakan. Analisis dilakukan menggunakan bantuan ArcGIS 10.3. Selanjutnya dilakukan analisis prediksi terhadap kemungkinan perubahan penggunaan lahan 10 tahun mendatang 20172026.

\subsection{Analisis Debit Puncak}

Analisis dilakukan untuk mengetahui perkembangan atau perubahan puncak debit yang terjadi di titik kontrol Bendung Gerak Serayu sepanjang tahun 2011-2016. Berdasarkan analisis data tersbut selanjutnya dilakukan analisis prediksi perkembangan atau peningkatan debit puncak selama 10 tahun mendatang 2017-2026 (Wijaya, K., 2011).

\subsection{Analisis Statistika Prediksi Peningkatan Puncak Debit Dan Penggunaan Lahan}

Analisis statistika digunakan untuk memprediksi hubungan perubahan penggunaan lahan dengan perubahan puncak debit yang terjadi di titik kontrol Bendung Gerak Serayu. Beberapa metode distribusi statistika yang digunakan antara lain Log Pearson Tipe III, Gumbel dan Logaritmik serta metode regresi (Fadholi, A., 2013, Munandar, D., 2015, Zhu, Y dan Gaoxia Jiang., 2011, Santosa, B., 2012).

\section{HASIL DAN PEMBAHASAN \\ 3.1 Penggunaan Lahan Kabupaten Banyumas Tahun 2011}

Berdasarkan interpretasi foto udara tahun 2011 dapat diketahui jenis - jenis penggunaan lahan yang terdapat di Kabupaten Banyumas sepoerti terdapat pada Gambar 3 dan Tabel 1. 


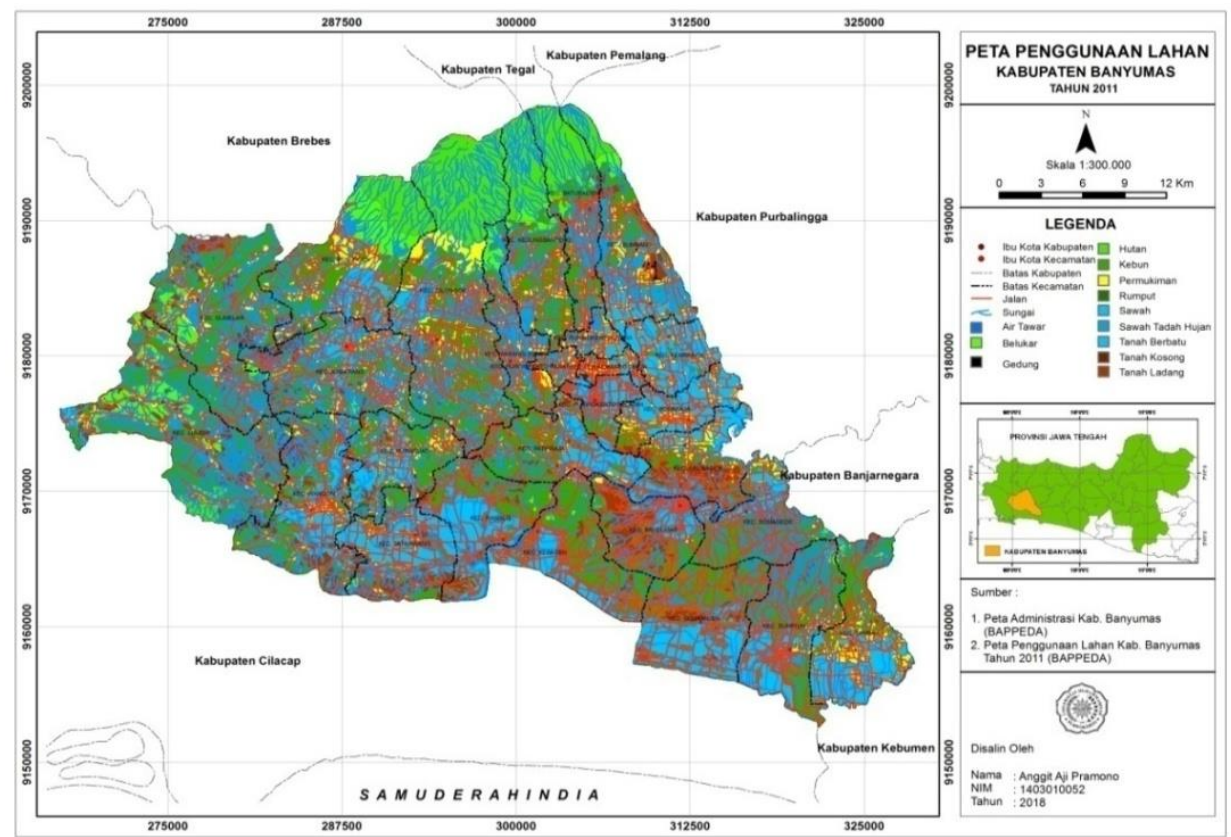

Gambar 3. Penggunaan Lahan Kabupaten Banyumas Tahun 2011 Sumber: Analisis, 2018 dan diolah dari Bappeda, 2012

Tabel 1. Penggunaan Lahan Kabupaten Banyumas Tahun 2011

\begin{tabular}{clrrr}
\hline & & \multicolumn{3}{c}{ Luas } \\
& & Penggunaan Lahan & \multicolumn{1}{c}{ Ha } & \multicolumn{1}{c}{$\mathrm{Km}^{2}$} \\
\hline 1 & Air Tawar & 1333,08 & 13,33 & 1,00 \\
2 & Sawah & 24684.09 & 246.84 & 18,59 \\
3 & Sawah Tadah Hujan & 7641,91 & 76,42 & 5,76 \\
4 & Hutan & 35678,97 & 356,79 & 26,88 \\
5 & Belukar & 1585,04 & 15,85 & 1,19 \\
6 & Rumput & 292,67 & 2,93 & 0,22 \\
7 & Kebun & 33570,21 & 335,70 & 25,29 \\
8 & Tanah Ladang & 2430,02 & 24,30 & 1,83 \\
9 & Tanah Berbatu & 9,57 & 0,10 & 0,01 \\
10 & Gedung & 89,14 & 0,89 & 0,07 \\
11 & Pemukiman & 21502,29 & 215,02 & 16,20 \\
12 & Lahan Kosong & 3941,01 & 39,41 & 2,97 \\
& Jumlah Total & 132758,00 & 1327,58 & 100 \\
\hline
\end{tabular}

Sumber :Analisis, 2018 dan Digitasi Foto Udara 2011

\subsection{Penggunaan Lahan Kabupaten Banyumas Tahun 2016}

Berdasarkan interpretasi foto udara tahun 2016 dapat diketahui jenis - jenis penggunaan lahan yang terdapat di Kabupaten Banyumas seperti dalam Gambar 4 dan Tabel 2. 


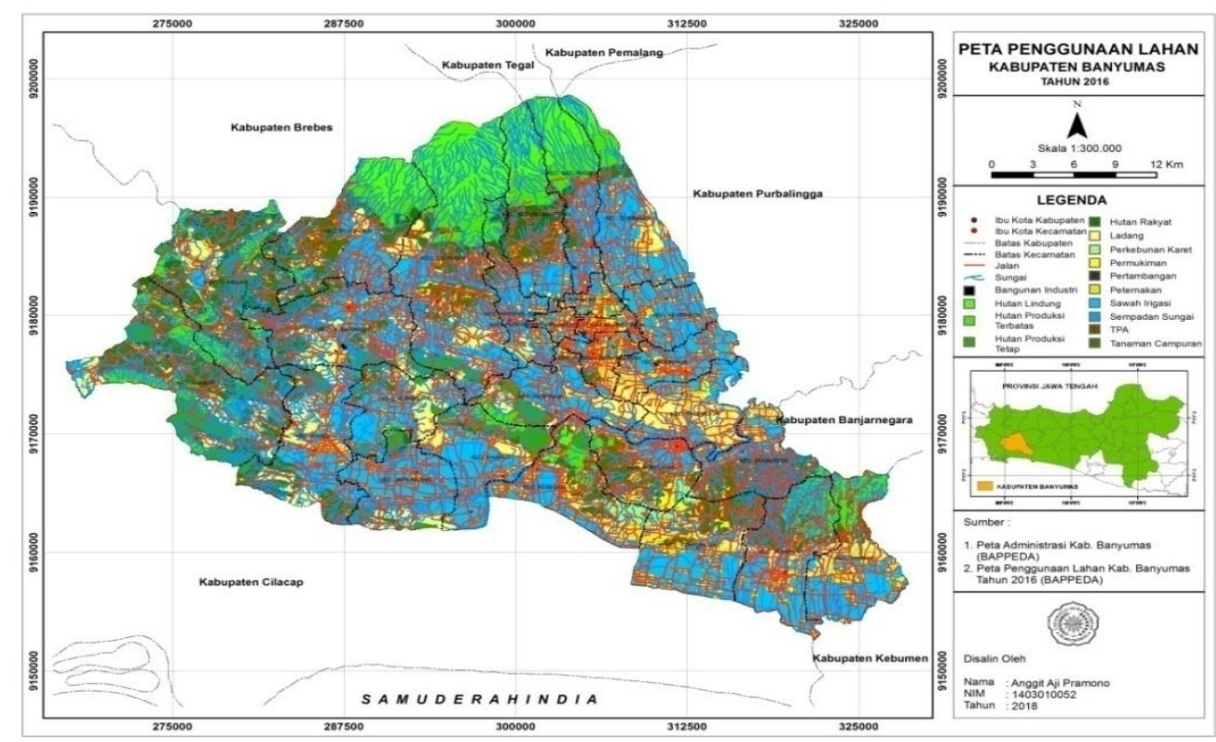

Gambar 4. Penggunaan Lahan Kabupaten Banyumas Tahun 2016 Sumber: Analisis, 2018 dan diolah dari Bappeda, 2017

Tabel 2. Penggunaan Lahan Kabupaten Banyumas Tahun 2016

\begin{tabular}{|c|c|c|c|c|}
\hline \multirow[b]{2}{*}{ No } & \multirow{2}{*}{ Penggunaan Lahan } & \multicolumn{3}{|c|}{ Luas } \\
\hline & & $\mathrm{Ha}$ & $\mathrm{Km}^{2}$ & $\%$ \\
\hline 1 & Sempadan Sungai & 2074,62 & 20,75 & 1,56 \\
\hline 2 & Sawah Irigasi & 32528,00 & 325,28 & 24,50 \\
\hline 3 & Hutan Lindung & 9496,36 & 94,96 & 7,15 \\
\hline 4 & Hutan Rakyat & 7655,34 & 76,55 & 5,77 \\
\hline 5 & Hutan Produksi Terbatas & 5895,64 & 58,96 & 4,44 \\
\hline 6 & Hutan Produksi Tetap & 5671,66 & 56,72 & 4,27 \\
\hline 7 & Perkebunan Karet & 28932,00 & 289,32 & 21,79 \\
\hline 8 & Ladang & 4447,00 & 44,47 & 3,35 \\
\hline 9 & Tanah Campur & 6928,00 & 69,28 & 5,22 \\
\hline 10 & Peternakan & 4,52 & 0,05 & 0,00 \\
\hline 11 & Pertambangan & 38,39 & 0,38 & 0,03 \\
\hline 12 & Bangunan Industri & 123,06 & 1,23 & 0,09 \\
\hline 13 & Pemukiman & 28950,32 & 289,50 & 21,81 \\
\hline 14 & TPA & 13,08 & 0,13 & 0,01 \\
\hline & Jumlah Total & $\begin{array}{r}132758,0 \\
0\end{array}$ & 1327,58 & 100 \\
\hline
\end{tabular}

Sumber :Analisis, 2018 dan Digitasi Foto Udara 2016

\subsection{Prediksi Debit Puncak}

Analisis prediksi peningkatan debit puncak dilakukan menggunakan beberapa model distribusi dan metode analisis regresi linear sederhana.
Tabel 3. Lahan Non Vegetasi Kabupaten Banyumas dan Debit Puncak Aliran Sungai Serayu di Titik Kontrol Bendung Gerak Serayu

\begin{tabular}{cccc}
\hline No. & Tahun & $\begin{array}{c}\text { Lahan Non } \\
\text { Vegetasi } \\
\text { (ha) }\end{array}$ & $\begin{array}{c}\text { Debit } \\
\text { Puncak } \\
\left(\mathrm{m}^{3} / \mathrm{s}\right)\end{array}$ \\
\hline 1 & 2011 & 21601 & 180,44 \\
2 & 2012 & 26227 & 589,83 \\
3 & 2013 & 38894 & 576.83 \\
4 & 2014 & 38913 & 692.72 \\
5 & 2015 & 38276 & 578.1 \\
6 & 2016 & 31204 & 660.35 \\
\hline
\end{tabular}

Sumber : Analisis, 2018 


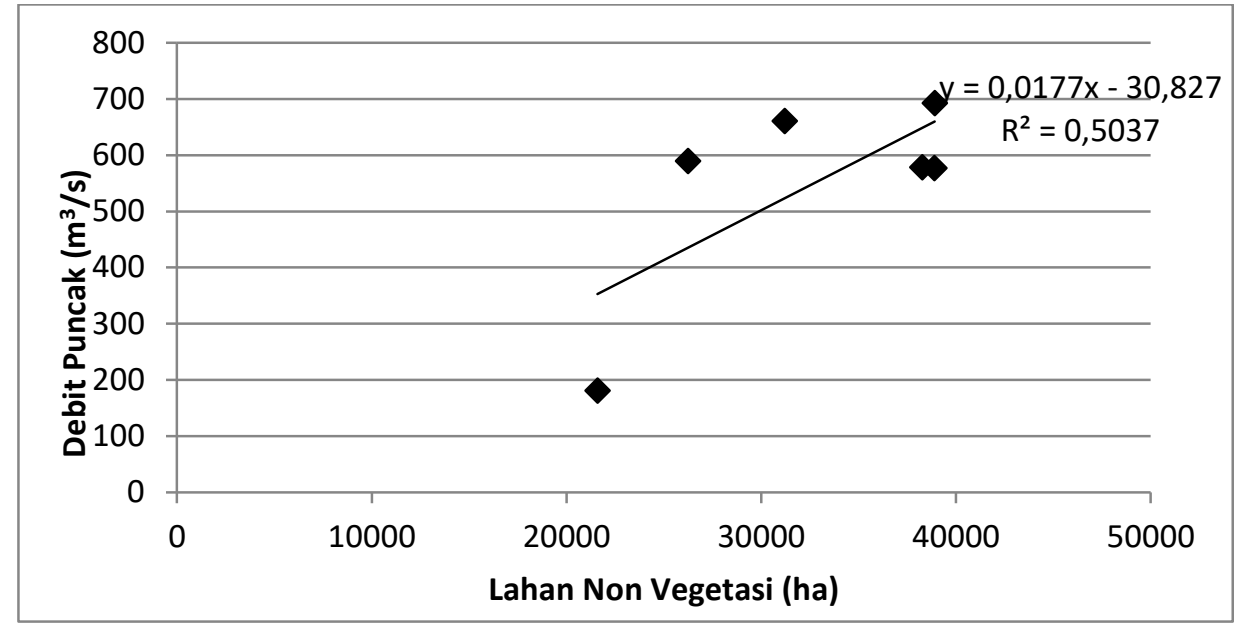

Gambar 5. Perubahan penggnaan lahan non Vegetasi

Sumber: Analisis, 2018

Gambar 5 menunjukan adanya hubungan yang cukup berpengaruh antara perubahan penggunaan lahan non vegetasi terhadap perubahan debit puncak di Hulu Bendung Gerak Serayu. Bedasarkan grafik tersebut nilai R2 = 0,503, hal ini menunjukkan bahwa 50,3\% peningkatan puncak debit dipengaruhi oleh perubahan penggunaan lahan.

Berdasarkan analisis di atas, selanjutnya dilakukan prediksi perubahan penggunaan lahan dan debit puncak untuk 10 tahun mendatang 2017-2026. Beberapa model persamaan prediksi yang digunakan meliputi model Log Pearson Tipe III, Gumbel dan logarithmic. Dari beberap model tersebut, model regresi logaritmik memberikan pendekatan yang paling baik dengan nilai $\mathrm{R} 2=$ 0,5613, sebagaimana terdapat pada Gambar 6 .

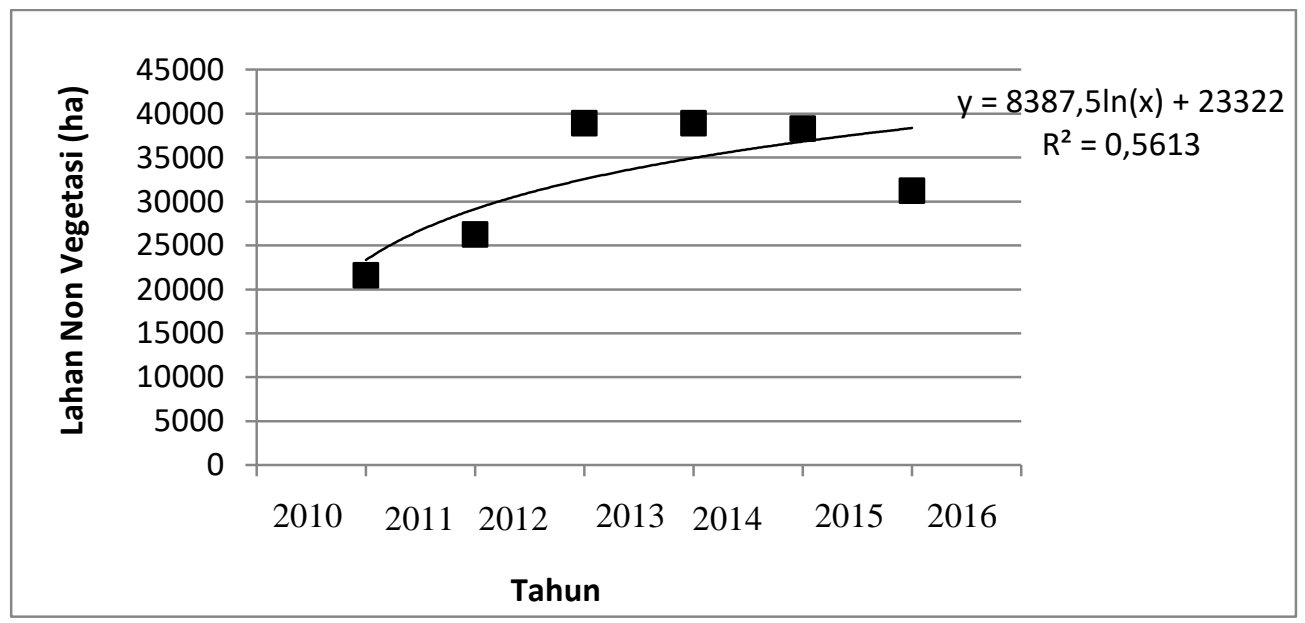

Gambar 6. Prediksi Perubahan Penggunaan Lahan menggunakan Model Logarithmic Sumber: Analisis, 2018

Berdasarkan analisis prediksi di atas, dapat dilihat hasil prediksi perubahan penggunaan lahan non vegetasi selama 10 tahun seperti dalam Tabel 4. 
Tabel 4. Hasil Prediksi Lahan Non Vegetasi Kabupaten Banyumas

\begin{tabular}{cc}
\hline Tahun & $\begin{array}{c}\text { Penggunaan Lahan } \\
\text { (ha) }\end{array}$ \\
\hline 2017 & 39642 \\
2018 & 40762 \\
2019 & 41750 \\
2020 & 42634 \\
2021 & 43433 \\
2022 & 44163 \\
2023 & 44834 \\
2024 & 45456 \\
2025 & 46034 \\
2026 & 46576 \\
\hline \multicolumn{2}{c}{ Sumber : Analisis 2018}
\end{tabular}

Selanjutnya prediksi peningkatan debit puncak selama 10 tahun mendatang dapat dilihat pada Tabel 5 dan Gambar 7 di bawah ini.
Tabel 5. Prediksi Debit Puncak di Titik Kontrol Bendung Gerak Serayu

\begin{tabular}{ccc}
\hline Tahun & $\begin{array}{c}\text { Penggunaan } \\
\text { Lahan (ha) }\end{array}$ & $\begin{array}{c}\text { Debit (m3/ } \\
\text { detik) }\end{array}$ \\
\hline 2017 & 39642 & 643,10 \\
2018 & 40762 & 662,14 \\
2019 & 41750 & 678,93 \\
2020 & 42634 & 693,95 \\
2021 & 43433 & 707,54 \\
2022 & 44163 & 719,95 \\
2023 & 44834 & 731,36 \\
2024 & 45456 & 741,93 \\
2025 & 46034 & 751,77 \\
2026 & 46576 & 760,97 \\
\hline
\end{tabular}

Sumber : Analisis 2018

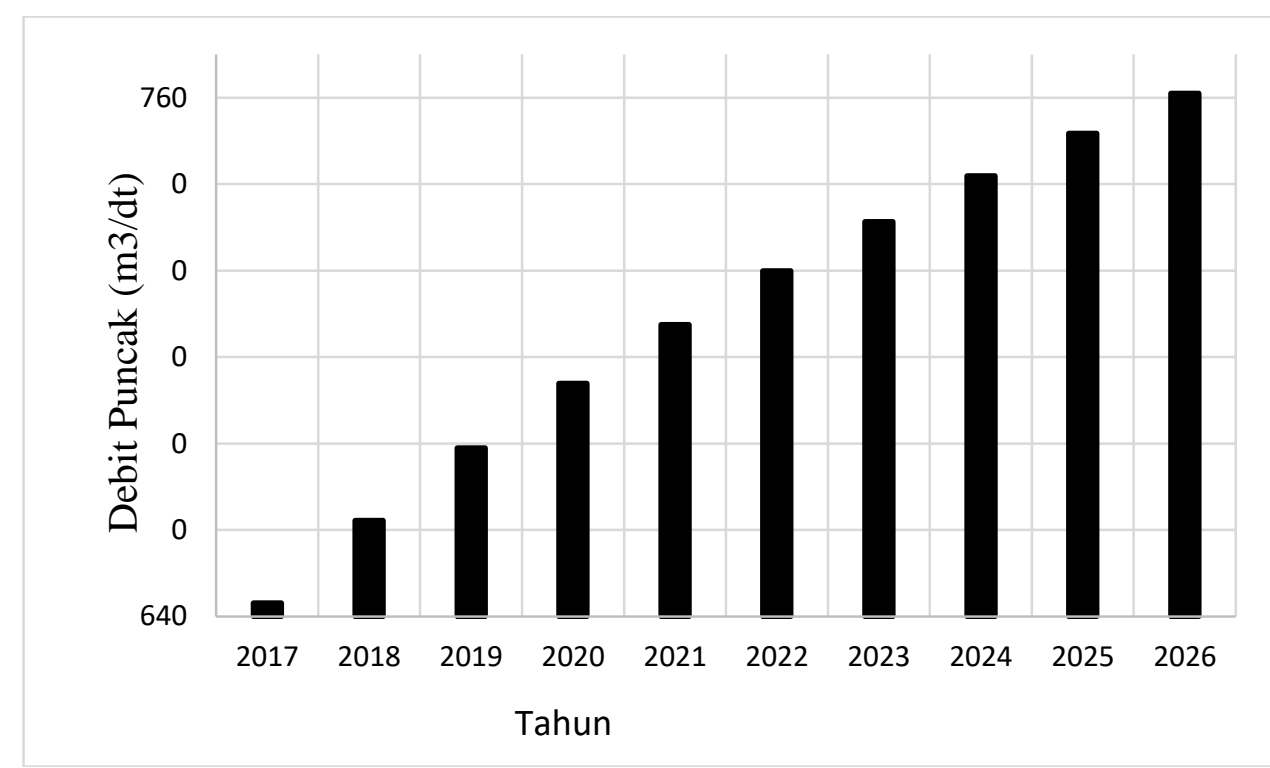

Gambar 7. Debit Puncak Sungai Serayu di Titik Kontrol Bendung Gerak Serayu Sumber : Analisis 2018

Berdasarkan Tabel 5 dan Gambar 7, debit puncak Sungai Serayu di Hulu Bendung Gerak Serayu 2017-2026 mempunyai kecenderungan naik setiap tahunnya. Kenaikan debit prediksi di titik kontrol Bendung Gerak Serayu salah satunya disebabkan oleh terjadinya perubahan penggunaan lahan di Kabupaten Banyumas atau di daerah Aliran Sungai Serayu di Hulu Bendung Gerak Serayu.

\section{KESIMPULAN}

Berdasarkan hasil penelitian dapat ditarik beberapa kesimpulan yaitu luas perubahan penggunaan lahan untuk kawasan vegetasi 2011-2016 mengalami penurunan sebesar $8,64 \%$, sedangkan lahan untuk kawasan non vegetasi mengalami kenaikan sebesar 44,46\%. Kenaikan debit puncak di titik kontrol Bendung Gerak Serayu salah satunya disebabkan oleh alih fungsi lahan atau karena peningkatan lahan non vegetasi. Prediksi debit puncak 2017-2026 di titik kontrol Bendung Gerak Serayu relatif 
mengalami kenaikan, yaitu : $\mathrm{Q}_{2017}=643,10$ $\mathrm{m}^{3} / \mathrm{s}, \mathrm{Q}_{2018}=662,14 \mathrm{~m}^{3} / \mathrm{s}, \mathrm{Q}_{2019}=678,93 \mathrm{~m}^{3} / \mathrm{s}$, $\mathrm{Q}_{2020}=693,95 \mathrm{~m}^{3} / \mathrm{s}, \mathrm{Q}_{2021}=707,54 \mathrm{~m}^{3} / \mathrm{s}, \mathrm{Q}_{2022}$

\section{Ucapan Terimakasih}

Penulis secara khusus mengucapkan terima kasih yang sebesar-besarnya kepada Kepada Badan Pusat Satatistika Kabupaten Banyumas, Balai Pengelolaan Sumber Daya Air Serayu Citandui Kabupaten Banyumas dan Badan Perencanaan Pembangunan dan Litbang Daerah Kabupaten Banyumas yang telah memberi bantuan pengumpulan data.

\section{DAFTAR PUSTAKA}

Anonim, 2017, Kabupaten Banyumas Dalam Angka, Badan Pusat Statistik Kabupaten Banyumas

Anonim, 2012, Peta Tutupan Lahan Kabupaten Banyumas, Badan Perencanaan Pembangunan dan Litbang Daerah Kabupaten Banyumas, 2012

Fadholi, A., 2013, Persamaan Regresi Prediksi Hujan Bulanan di Pontianak Dengan Prediktor Suhu dan Kelembaban Udara. Vol 10 no. 2: 230 - 241. Pangkalpinang: Stasiun Meteorologi Depati Amir.

Google Maps, 2018, Peta Kabupaten Banyuma.. Tersedia dalam: https://www. google.com/maps/place/Kabupaten+ Banyumas,+Jawa+Tengah/@7.4549795, $109.0284843,11 \mathrm{z} /$ data $=! 3 \mathrm{~m} 1 ! 4 \mathrm{~b} 1 \mathrm{!m}$ 5!3m4!1s0x2e656746bfbcb0fd:0x302 $7 \mathrm{a} 76 \mathrm{e} 352 \mathrm{ba} 60$ ! $8 \mathrm{~m} 2$ ! $3 \mathrm{~d}-$ 7.4832133!4d109.140438?hl=id. [Accessed 1 Maret 2018].

Munandar, D., 2015, Optimization Weather Parameters Influencing Rainfall Prediction Using Adaptive Networkbased Fuzzy Inference System (ANFIS) and Linier Regression. 978-1-46738430-8/15/\$31.00 (C)2015 IEEE, pp.
$=719,95 \mathrm{~m}^{3} / \mathrm{s}, \mathrm{Q}_{2023}=731,36 \mathrm{~m}^{3} / \mathrm{s}, \mathrm{Q}_{2024}=$ $741,93 \mathrm{~m}^{3} / \mathrm{s}, \mathrm{Q}_{2025}=751,77 \mathrm{~m}^{3} / \mathrm{s}, \mathrm{Q}_{2026}=760,97$ $\mathrm{m}^{3} / \mathrm{s}$.

154-159 2015. Bandung, Indonesia: Pusat Penelitian untuk Informatika Lembaga Ilmu Pengetahuan Indonesia.

Nilda. (2014). Analisis Perubahan Penggunaan Lahan Dan Dampaknya Terhadap Hasil Air Di Daerah Aliran Sungai Cisadane Hulu, Tesis. Denpasar: Universitas Udayana Denpasar.

Pratama, W. (2016). Analisis Perubahan Penggunaan Lahan Terhadap Karakteristik Hidrologi di DAS Bulok, Skripsi. Bandar Lampung: Universitas Lampung.

Sudarto. (2009). Analisis Pengaruh Perubahan Tata Guna Lahan Terhadap Peningkatan Jumlah Aliran Permukaan, Tesis. Surakarta: Universitas Sebelas Maret.

Wahyunto, M.Z. Abidin, A. Priyono, dan Sunaryo. (2001). Studi Perubahan Penggunaan Lahan Di Sub DAS Citarik, Jawa Barat dan DAS Kaligarang, Jawa Tengah. Prosiding Seminar Nasional Multifungsi Lahan Sawah. Bogor: Balai Penelitian Tanah.

Wijaya, K. (2011). Dampak Perubahan Penggunaan Lahan Di Das Gung Hulu Terhadap Debit Sungai Gung Kabupaten Tegal, Skripsi. Semarang: Universitas Negeri Semarang.

Zhu, Y dan Gaoxia Jiang., 2011, Hierarchical Linear Model and Its Research on Hierarchical Characteristics of Rainfall. 978-1 61284-774-0/11/\$26.00 (C)2011 IEEE, pp. 2146-2150 2011. Beijing, China: Mathematics and physics department North China Electric Power University. 